\title{
-Originals-
}

\section{Presence of endothelin-1 in human salivary glands and tumors}

\author{
Munenaga Nakamizo, Ruby Pawankar, Kimihiro Ohkubo \\ Department of Otorhinolaryngology, Nippon Medical School
}

\begin{abstract}
To elucidate the presence and distribution of Endothelin-1 (ET-1) in tissues of human salivary glands, we performed an immunohistochemical analysis of ET-1 in 15 normal salivary glands, 8 adenolymphomas, 13 pleomorphic adenomas and 5 carcinomas, using the mouse monoclonal antibody against human ET-1. In normal glands, immunoreactivity for ET-1 was observed in the striated duct cells. In adenolymphomas, the columnar cells of the granular epithelium showed strong intracytoplasmic immunoreactivity. In carcinomas, moderate or strong immunoreactivity was observed in the tumor cells, whereas in pleomorphic adenomas, weak immunoreactivity was observed. A good relation was detected between the size of pleomorphic adenoma and ET-1 immunoreactivity, as well as between the duration of tumor in carcinoma and ET-1 immunoreactivity. The presence and distribution of ET-1 in salivary glands and salivary gland tumors suggests a possible role for ET-1 in the regulation of electrolytes and water transport in salivary glands, and as a growth-promoting factor for tumors. (J Nippon Med Sch 1998; $65: 471-477$ )
\end{abstract}

Key words: salivary gland, salivary gland tumor, endothelin-1, immunohistochemistry, growth factor.

\section{Introduction}

Endothelin (ET) is a 21 amino acid peptide, first isolated from the culture medium of in vitro cultured endothelial cells of porcine vessels, and shown to be a vasoconstrictor'. However, it was reported that ET exists not only in the blood vessel endothelium but also in many other tissues, such as in the lung epithelium ${ }^{2}$, inner kidney medulla ${ }^{3}$, thyroid gland $^{4}$ and lacrimal gland ${ }^{5}$. ET has three isoforms (ET-1, ET-2, ET-3), which are encoded by three separate genes. In blood vessels, endothelins (ETs) appear to have two functions ${ }^{7.8}$, which are the regulation of endothelial cell proliferation (autocrine), and the contraction and mitogenesis of vascular smooth muscle cells (paracrine). It is also reported that ET inhibits $\mathrm{Na}^{+}-\mathrm{K}^{+}$-ATPase in renal tubular epithelium ${ }^{9}$, and has effects on water and chloride transport in the collecting ducts of the rat kidney ${ }^{10}$. Furthermore, it was reported that ET-1 stimulates the proliferation of fibroblasts ${ }^{11}$, rat mesangial cells $\mathrm{s}^{12}$, and a cancer cell line ${ }^{13}$, suggesting a possible role for this peptide as a growth factor.

The salivary gland is a well-known excretory gland and is mainly involved in the production and secretion of saliva. It is also a site of origin of many benign and malignant tumors. However, there is only one report on the presence and distribution of ET in the salivary glands ${ }^{14}$.

In order to elucidate the presence and distribution of ET-1 in normal and pathological human salivary glands, we examined the presence of ET-1 in normal salivary glands as well as in salivary gland tumors, using an immunohistochemical method. 


\section{Materials and Methods}

Seven patients ( $M: F=6: 1$, including one patient with bilateral lesion) with adenolymphoma, 13 patients ( $\mathrm{M}: \mathrm{F}=4: 9$ ) with pleomorphic adenoma and 5 patients ( $\mathrm{M}: \mathrm{F}=2: 3)$ with carcinoma were included in this study after obtaining informed consent according to the hospital regulations. The age distribution of the patients with adenolymphoma was 48-67 yrs with an average age of 58.7 yrs. The age range of those with pleomorphic adenoma was $26-76 \mathrm{yrs}$, with a mean age of $46.4 \mathrm{yrs}$, and the age range of those with carcinoma was 56 . $75 \mathrm{yrs}$, with a mean age of $69.0 \mathrm{yrs}$. Among the patients with carcinoma, one had adenocarcinoma, two had adenoid cystic carcinoma, and the others had mucoepidermoid carcinoma (a case with highgrade malignant mucoepidermoid carcinoma, and a case with carcinoma in pleomorphic adenoma). Normal salivary gland tissues were obtained at the time of excision of these benign tumors. After fixation of the specimens in PLP (periodate lysine paraformaldehyde) overnight at $4^{\circ} \mathrm{C}$, these specimens were embedded in paraffin. Subsequently 5 $\mu \mathrm{m}$ thick sections were cut using a microtome (Yamato Kohki Kogyo Co., Ltd. Tokyo, Japan), deparaffinized by immersion in xylene and graded series of ethanol $(30-100 \%)$ and processed for immunohistochemistry as previously described ${ }^{15}$. Briefly, these specimens were rehydrated in Tris $\mathrm{HCl}$ buffered saline (TBS) $0.05 \mathrm{M}$ (pH 7.6), and non-specific binding was blocked by incubating the sections in $10 \%$ normal rabbit serum for 15 minutes. The sections were then treated with mouse antihuman ET-1 monoclonal antibody (Yamasa Shoyu Co., Ltd. Chiba, Japan) at a dilution of $1: 100$ for 1 hour at room temperature. The sections were then rinsed in TBS and stained by the alkalinephosphatase-anti-alkaline phosphatase method (APAAP kit; DAKO, Santa Barbara, CA, USA), according to the manufacturer's instructions. The reaction was developed using the Naphtol AS MX Fast-Red TR substrate for 8 minutes in all cases. Mayer's hematoxylin was used for nuclear staining and the sections were mounted with glycerol gel (DAKO). All specimens were processed in exactly the same manner. As a negative control isotype- matched monoclonal antibody (mouse myeloma IgG 1 ; DAKO) was used instead of the primary antibody at a dilution of $1: 100$. Normal human kidney tissue was used as a positive control.

\section{Intensity of Immunoreactivity}

Based on the intensity of the color reaction as observed by light microscopy, we classified the degree of immunoreactivity into three grades, weak + , moderate ++ , strong +++ .

\section{Results}

\section{Normal salivary gland tissue}

Fig. 1A shows an example of the presence of ET 1 in normal salivary gland tissue. The striated duct cells of the normal salivary glands exhibited moderate immunoreactivity to ET-1. On the other hand, the acinar cells and intercalated duct cells did not exhibit immunoreactivity for ET-1. Excretory ducts exhibited moderate immunoreactivity. In 4 out of 12 cases in which the normal parotid capsule was resected, ET-1 immunoreactivity was detected in a few of the mononuclear cells in the capsule. No staining was detected in the normal salivary gland tissue with the isotype-matched control antibody (Fig. 1B) .

\section{Adenolymphoma and pleomorphic adenoma}

In adenolymphomas, the presence of ET-1 was detected in the double-layered granular epithelium of the tumor cells. The intensity of immunoreactivity in the columnar cells (the apical row of cells) was strong, whereas that of the basal cells (inner layer of cells) was weak (Fig. 2A, B). In the lymphoid stroma of the tumor, less than $30 \%$ of the mononuclear cells demonstrated strong immunoreactivity for ET-1. In 5 out of 6 adenolymphomas, the presence of ET-1 was detected in the capsullar mononuclear cells of the tumor. No staining was detected in the adenolymphoma with the isotypematched control antibody (Fig. 2C).

In pleomorphic adenomas, ET-1 immunoreactivity was detected in the tumor cells of all cases examined. However, the intensity of immunoreactivity was weak in 10 out of 13 cases (Fig. 3A). No ET-1 immunoreactivity was detected in the stroma of the tumors. On the other hand, the presence of ET-1 was detected in the capsullar mononuclear 

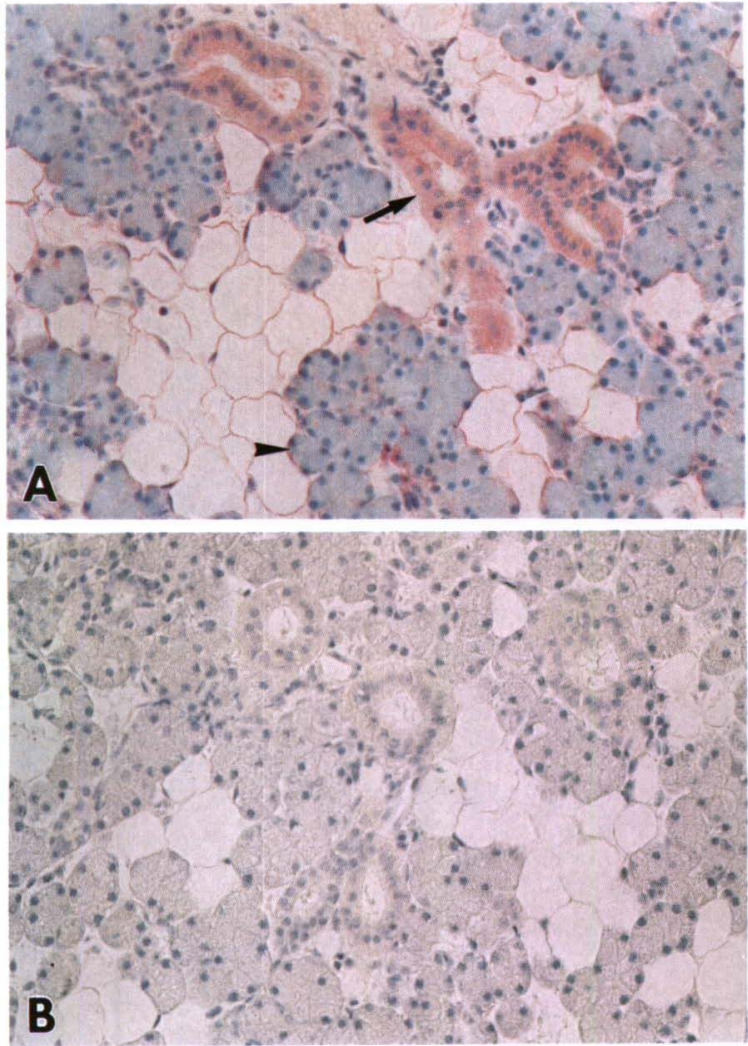

Fig. 1 Immunoreactivity for ET-1 in the normal salivary gland. Normal salivary glands were stained with the mouse anti-human ET-1 monoclonal antibody using the APAAP method as described in the text. A) ET-1 presence was detected in the striated duct cells (arrow), but not in the acinar cells (arrow head) $(\times 60)$. B) As a negative control, primary antibody was substituted with the isotype-matched antibody (Mouse myeloma IgG1). No staining could be detected $(\times 67)$.

cells. No staining was detected in the pleomorphic adenoma with the isotype-matched control antibody (Fig. 3B).

\section{Carcinoma}

In carcinomas, ET-1 immunoreactivity was detected in the tumor cells of all cases examined. The immunoreactivity for ET-1 was either strong or moderate in 4 out of 5 cases. In one case with a high-grade malignant mucoepidermoid carcinoma of 5 months duration, immunoreactivity for ET-1 was strong (Fig. 4A). No ET-1 immunoreactivity was detected in the stroma or mononuclear lymphoid cells of the tumors. No staining was detected in the mucoepidermoid carcinoma with the isotype-matched control antibody (Fig. 4B).
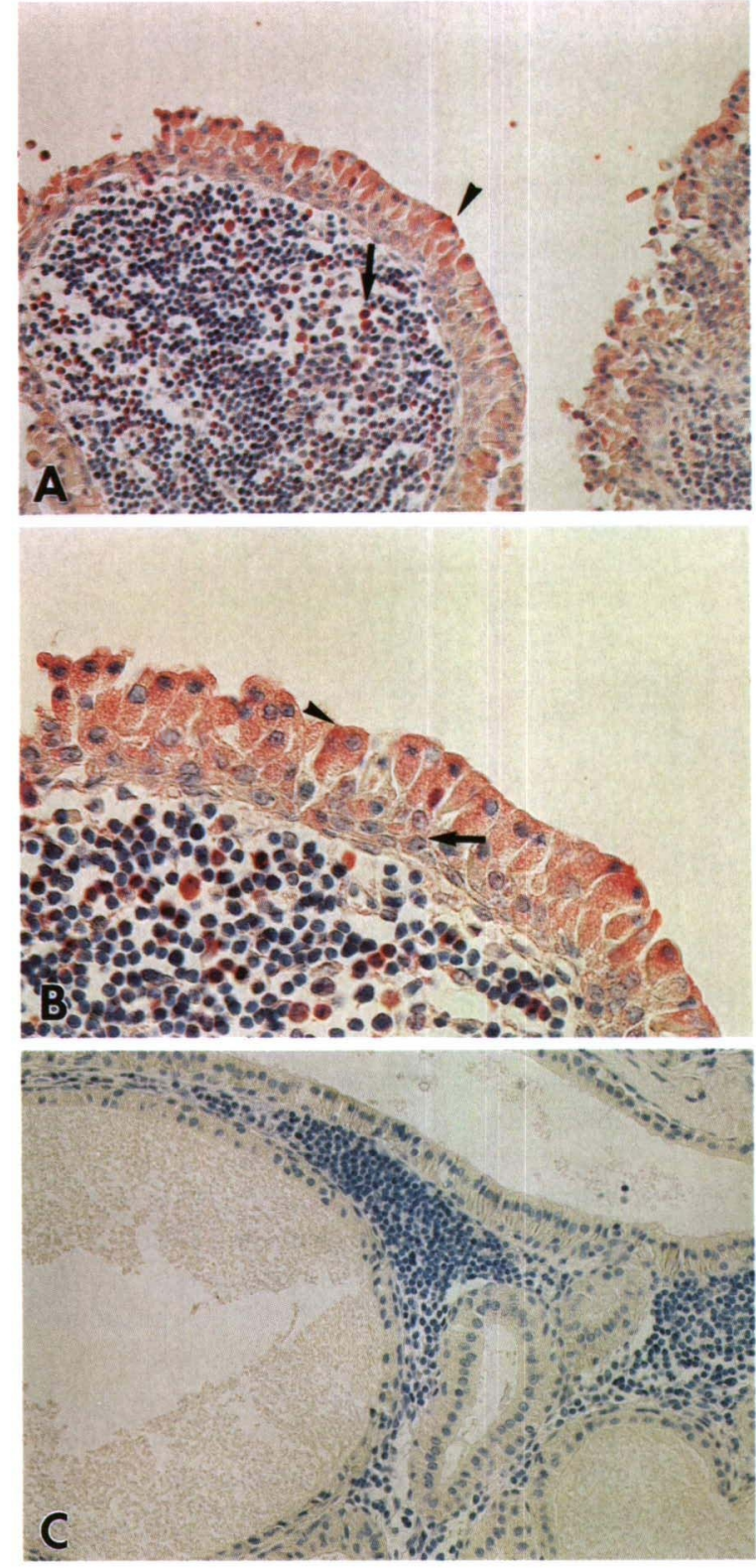

Fig. 2 Immunoreactivity for ET-1 in adenolymphoma. Adenolymphomas were stained with the mouse anti-human ET-1 monoclonal antibody using the APAAP method as described in the text. A) ET-1 presence was detected in the double-layered granular epithelial cells (arrow head) and in less than $30 \%$ of mononuclear cells (arrow) in the lymphoid stroma $(\times 60)$. B) Strong immunoreactivity was detected in the columnar cells of the double-layered granular epithelial cells (arrow head), whereas in the basal cells (arrow) it was weak $(\times 120)$. C) As a negative control, primary antibody was substituted with the isotype-matched antibody. No staining could be detected $(\times 67)$.

Relation of immunoreactivity for ET-1 to the duration and size of tumor

Table 1, shows the duration, the tumor size of 


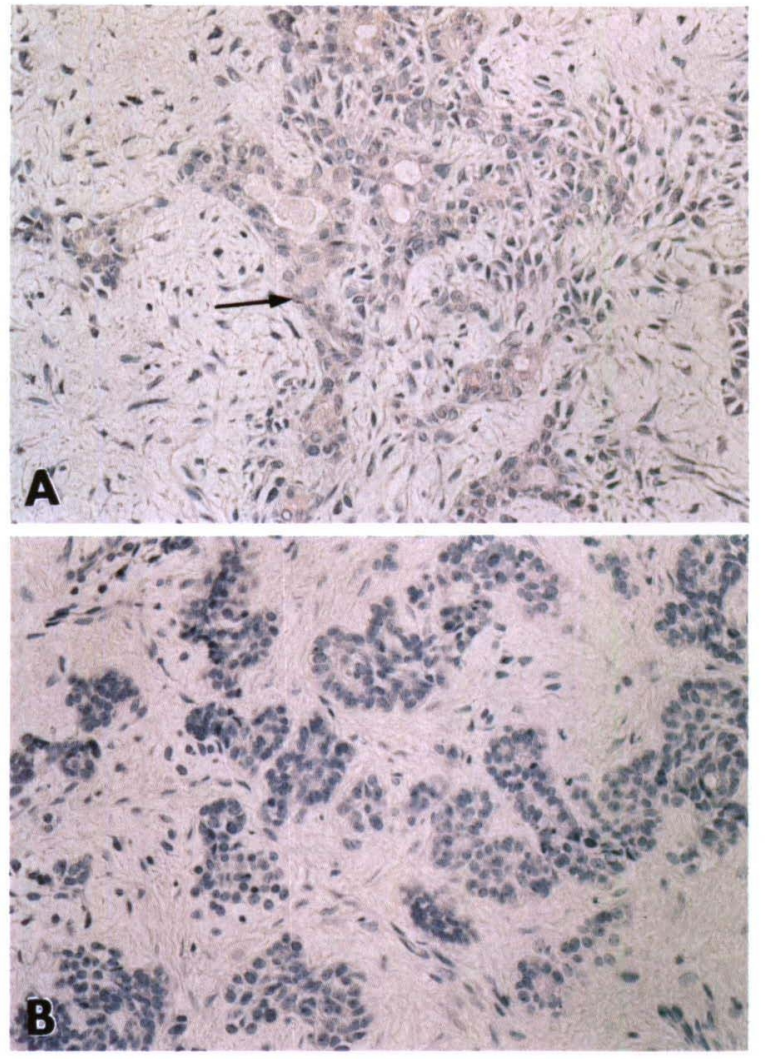

Fig. 3 Immunoreactivity for ET-1 in pleomorphic adenoma. Pleomorphic adenomas were stained with mouse anti-human ET-1 monoclonal antibody using the APAAP method as described in the text. A) Weak ET-1 immunoreactivity was detected in the tumor cells (arrow). However, intracytoplasmic immunoreactivity was not seen in all tumor cells $(\times 67)$. B) As a negative control, primary antibody was substituted with the isotype-matched antibody. No staining could be detected $(\times 69.5)$.

each patient with adenolymphoma prior to surgery, and the intensity of ET-1 immunoreactivity. Table 2 , shows the duration, the tumor size of each patient with pleomorphic adenoma, and the intensity of ET-1 immunoreactivity. Table 3, shows the pathological diagnosis, the duration, the tumor size of each patient with carcinoma, and the intensity of ET-1 immunoreactivity. No relation could be observed between the intensity of ET-1 immunoreactivity and the duration or tumor size in the cases with adenolymphoma.

In pleomorphic adenomas, when the maximum diameter of the tumor was less than $40 \mathrm{~mm}$, the immunoreactivity for ET-1 was weak. However, in 3 out of 5 cases with pleomorphic adenoma in which the maximum diameter of the tumor exceeded 40

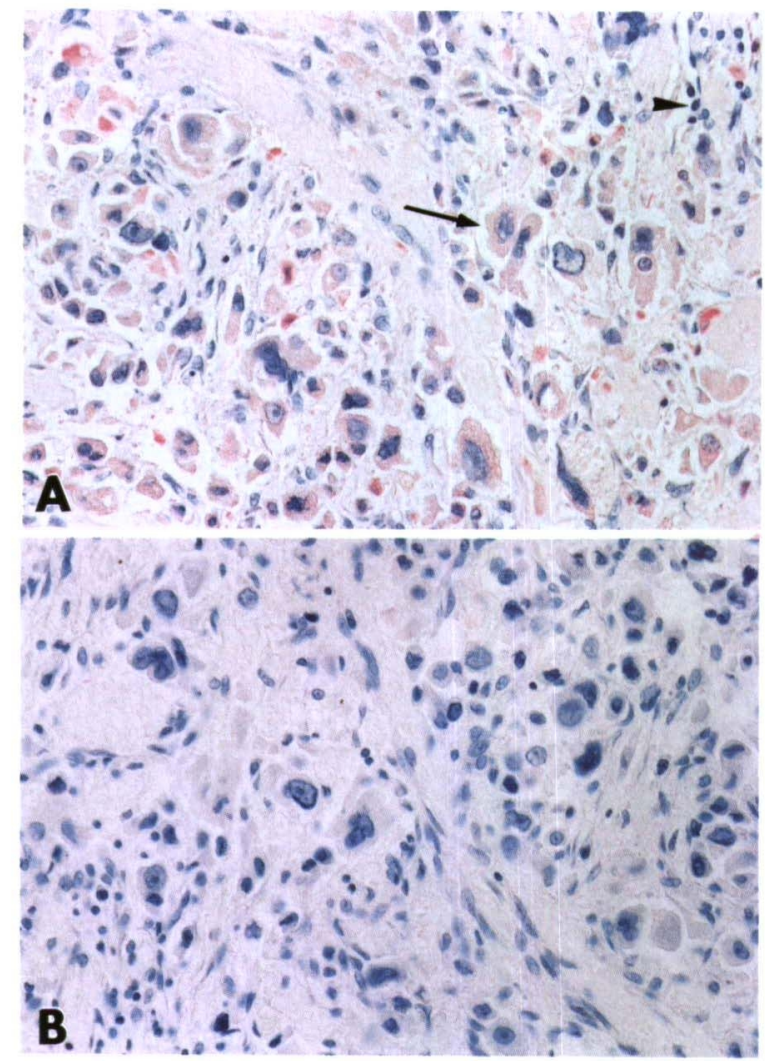

Fig. 4 Immunoreactivity for ET-1 in carcinoma. Mucoepidermoid carcinoma was stained with mouse anti-human ET-1 monoclonal antibody using the APAAP method as described in the text. A) Strong ET-1 immunoreactivity was detected in the tumor cells (arrow). However, ET-1 immunoreactivity was not seen in mononuclear lymphoid cells or stroma (arrow head) $(x$ 75). B) As a negative control, primary antibody was substituted with the isotypematched antibody. No staining could be detected $(\times 75)$.

Table 1 Duration, tumor size and ET-1 immunoreactivity of adenolymphoma

\begin{tabular}{|c|c|c|c|}
\hline \# & Duration & Size & $\begin{array}{l}\text { Intensity of ET-1 } \\
\text { immunoreactivity }\end{array}$ \\
\hline 1 & $6 \mathrm{y}$ & $45 \times 38$ & + \\
\hline 2 & 5 y $6 \mathrm{~m}$ & $51 \times 43$ & 世 \\
\hline 3 & $4 \mathrm{y}$ & $40 \times 35$ & H \\
\hline 4 & $3 y$ & $28 \times 23$ & m \\
\hline 5 & $6 \mathrm{~m}$ & $21 \times 17$ & + \\
\hline 6 & $6 \mathrm{~m}$ & $20 \times 20$ & + \\
\hline 7 & $4 \mathrm{~m}$ & $37 \times 20$ & H \\
\hline 8 & $1 \mathrm{~m}$ & $45 \times 40$ & H \\
\hline
\end{tabular}

$\mathrm{y}$ : year, $\mathrm{m}$ : month, $\mathrm{m}$ : strong, + : moderate, + : weak 
$\mathrm{mm}$, the intensity of immunoreactivity was either moderate or strong.

In carcinomas, the duration of tumors was different in each case according to the grade of malignancy. Three out of 5 tumors were slow-growing. Although the size of the tumors in 4 cases was about the same, around $40 \mathrm{~mm}$, the intensity of ET-1 immunoreactivity was strong in only one case with high-grade malignant mucoepidermoid carcinoma. Even though this tumor was of a short-duration and had metastasized to the cervical lymph nodes, the size of the tumor matched that of the slow growing tumors, suggesting that ET-1 may play a role as a growth factor in rapidly growing carcinoma of the salivary gland.

\section{Discussion}

The salivary gland is a well-known excretory

Table 2 Duration, tumor size and ET-1 immunoreactivity of pleomorphic adenoma

\begin{tabular}{r|lcc}
\hline$\#$ & Duration & Size & $\begin{array}{c}\text { Intensity of ET-1 } \\
\text { immunoreactivity }\end{array}$ \\
\hline 1 & $3 \mathrm{y}$ & $60 \times 50$ & + \\
2 & $17 \mathrm{y}$ & $45 \times 43$ & + \\
3 & $10 \mathrm{y}$ & $45 \times 23$ & + \\
4 & $1 \mathrm{y} 6 \mathrm{~m}$ & $40 \times 35$ & + \\
5 & $10 \mathrm{y}$ & $40 \times 30$ & + \\
6 & $1 \mathrm{y}$ & $35 \times 35$ & + \\
7 & $4 \mathrm{y}$ & $35 \times 25$ & + \\
8 & $3 \mathrm{~m}$ & $30 \times 30$ & + \\
9 & $2 \mathrm{~m}$ & $30 \times 30$ & + \\
10 & $2 \mathrm{~m}$ & $30 \times 28$ & + \\
11 & $1 \mathrm{y}$ & $30 \times 25$ & + \\
12 & $1 \mathrm{~m}$ & $25 \times 25$ & + \\
13 & $4 \mathrm{y} 6 \mathrm{~m}$ & $20 \times 15$ & + \\
\hline
\end{tabular}

$\mathrm{y}$ : year, $\mathrm{m}$ : month, $\#$ : strong, + : moderate, + : weak gland and has the function of producing and secreting saliva. Although the presence of immunoreactivity for ET by radioimmunoassay in the rat parotid gland was reported ${ }^{14}$, there are no reports of ET-1 expression in normal human salivary glands or salivary gland tumors. In the present study, we detected ET-1 immunoreactivity in normal salivary glands as well as in salivary gland tumors.

In the normal salivary gland, it is well known that one of the function of the duct system is to exchange water and electrolytes during the passage of saliva through the duct ${ }^{16}$. The striated duct has been reported to be the main site of exchange for electrolytes ${ }^{17}$ and is rich in mitochondria. Sodium ions $\left(\mathrm{Na}^{+}\right)$in the salivary fluid are reabsorbed from the lumen of the striated duct and transported into the blood vessels. On the other hand, potassium $\left(\mathrm{K}^{+}\right)$ ions are transported from the blood into the saliva ${ }^{17}$. It is reported that ET plays a role in the inhibition of $\mathrm{Na}^{+}-\mathrm{K}^{+}-\mathrm{ATPase}^{9}$ and has effects on water and chloride transport ${ }^{10}$ in the kidney. In this study, ET. 1 immunoreactivity was similarly detected in the striated duct. The co-localization of ET-1 and mitochondria in the striated ducts suggests its involvement in the regulation of water and electrolyte transport in the salivary gland.

Takashima et al, reported that ET-1 immunoreactivity was detected in the duct of the lacrimal gland $^{5}$. The presence of ETs in the epithelium, namely in the collecting duct of the the kidney, the duct of the lacrimal gland, and the striated duct of the salivary gland, suggests its role in the inhibition of $\mathrm{Na}^{+}-\mathrm{K}^{+}$-ATPase in the duct system. In adenolymphomas, ET-1 immunoreactivity was detected in the columnar cells of the granular epithelium of the tumor. The presence of ET-1 at this site also may suggest its role in the inhibition of $\mathrm{Na}^{+}-\mathrm{K}^{+}$-ATPase.

Table 3 Pathology, duration, tumor size and ET-1 immunoreactivity of carcinoma

\begin{tabular}{c|cccc}
\hline$\#$ & $\begin{array}{c}\text { Pathological } \\
\text { diagnosis }\end{array}$ & Duration & Size (TNM) & $\begin{array}{c}\text { Intensity of ET-1 } \\
\text { immunoreactivity }\end{array}$ \\
\hline 1 & AC & $2 \mathrm{~m}$ & $19 \times 18(\mathrm{~T} 1 \mathrm{~N} 0)$ & $\#$ \\
2 & MEC & $5 \mathrm{~m}$ & $37 \times 37(\mathrm{~T} 2 \mathrm{~N} 1)$ & $\#$ \\
3 & MEC & $4 \mathrm{y} 5 \mathrm{~m}$ & $40 \times 32(\mathrm{~T} 2 \mathrm{~N} 0)$ & + \\
4 & ACC & $7 \mathrm{y} 6 \mathrm{~m}$ & $45 \times 35(\mathrm{~T} 4 \mathrm{~N} 0)$ & + \\
5 & ACC & $8 \mathrm{y}$ & $42 \times 42(\mathrm{~T} 3 \mathrm{~N} 0)$ & + \\
\hline
\end{tabular}

TNM classification (fifth edition) adapted. AC: adenocarcinoma, MEC: mucoepidermoid carcinoma, ACC : adenoid cystic carcinoma, y : year, $m:$ month, $H:$ strong, $+:$ moderate, + : weak. 
As to the histogenesis of the parotid gland and tumor, the bicellular theory ${ }^{18,19}$ is generally accepted. According to the theory, adenolymphoma originates during the process of differentiation of the intercalated reserve cells to the striated duct. Based on the role of the striated duct in water and electrolyte transport, it is reasonable to suppose that the columnar epithelium of adenolymphomas may also have a similar function. Moreover, a recent report about the localization of mitochondria and $\mathrm{Na}^{+}-\mathrm{K}^{+}$-ATPase in the adenolymphoma revealed not only the morphological but also the functional similarity between striated duct cells and tumor cells of the adenolymphoma ${ }^{20}$. These researchers reported that $\mathrm{Na}^{+}-\mathrm{K}^{+}$-ATPase was localized mainly to the columnar epithelial cells of the adenolymphoma. Our results demonstrating colocalization of ET-1 in the striated ducts and columnar epithelium of adenolymphomas suggest a morphological and functional similarity between the striated ducts and columnar epithelium of adenolymphomas.

Some researchers have reported that ET-1 stimulates the proliferation of rat vascular smooth muscle cells ${ }^{7,8}$, fibroblasts and rat mesangial cells ${ }^{11,12,21}$. It is also reported that ET-1 is synthesized by and released from human epithelial carcinoma cell lines, and that exogenous and endogenous ET-1 stimulates the proliferation of tumor cells ${ }^{13}$. Interestingly, in pleomorphic adenomas (benign tumors) we found that there was a good relation between the size of tumor and the intensity of ET-1 immunoreactivity. Moreover, in carcinomas, we found a good relation between the duration of tumor (rapidity of growth) and the ET-1 immunoreactivity. These results suggest an important role for ET-1 as a growthpromoting factor in salivary gland tumors. Similar observations have been made by other researchers who have reported that ET-1 functions as a growthpromoting factor for human thyroid epithelial cells $^{22}$, gliomas ${ }^{23}$, and breast cancer ${ }^{24}$. Further studies on the presence of ET receptors and the kinetics of ET-1 and ET-1 receptor expression are underway to elucidate the precise roles of ET-1 in salivary glands and salivary gland tumors.

Acknowledgments : We would like to express our sincere gratitude to Professor Toshiaki Yaki for his excellent suggestions and editing of the manuscript. We would also like to thank Dr. Ken Jinnouchi and all the doctors in the Department for their kind support.

\section{References}

1. Yanagisawa M, Kurihara H, Kimura S, Tomobe $Y$, Kobayashi M, Yazaki Y, Goto K, Masaki T: A novel potent vasoconstrictor peptide produced by vascular endothelial cells. Nature (Lond.) 1988 ; 332 : 411-415.

2. Rozengurt N, Springall DR, Polak JM : Localization of endothelin-like immunoactivity in airway epithelium of rats and mice. J Pathol 1990; 160:5-8.

3. Kitamura K, Tanaka T, Kato J, Eto T, Tanaka K : Regional distribution of immunoreactive endothelin in porcine tissue: Abundance in inner medulla of kidney. Biochem Biophys Res Commun 1989; 161 : 348-352.

4. Lenziardi M, Viacava P, Fiorini I, Casragna M, Nardini V, Pollina L, De Negri F, Goletti O, Di Coscio $G$, Bevilacqua $G$ : Presence of endothelin-1 in the normal and pathological human thyroid. $\mathbf{J}$ Endocrinol Invest $1995 ; 18: 336-340$.

5. Takashima Y, Takagi H, Takahashi M, Reinach PS, Mircheff AK, Warren DW, Yoshimura N: Endothelin protein expression in tear glands of the rabbit. Curr Eye Res 1996; 15: 768-773.

6. Inoue A, Yanagisawa M, Kimura S, Kasuya Y, Miyauchi T, Goto K, Masaki T: The human endothelin family: Three structurally and pharmacologically distinct isopeptides predicted by three separate genes. Proc Natl Acad Sci USA $1989 ; 86: 2863-2867$.

7. Rubanyi GM, Parker Botelho LH: Endothelins. FASEB J 1991 ; 5 : 2713-2720.

8. Simonson MS, Dunn MJ: Cellular signaling by peptides of the endothelin gene family. FASEB $J$ $1990 ; 4: 2989-3000$.

9. Zeidel ML, Brady H, Kone B, Gullans S, Brenner BM : Endothelin, a peptide inhibitor of $\mathrm{Na}^{+}-\mathrm{K}^{+}$. ATPase in intact renal tubular epithelial cells. Am J Physiol 1989; 257 (Cell Physiol. 26) : C 1101C 1107.

10. Tomita K, Nonoguchi H, Terada Y, Marumo F: Effects of ET-1 on water and chloride transport in cortical collecting ducts of the rat. Am J Physiol 1993; 264 (Renal Fluid Electrolyte Physiol. 33): F 690-F 696.

11. Takuwa N, Takuwa Y, Yanagisawa M, Yamashita K, Masaki T: A novel vasoactive peptide endoth elin stimulates mitogenesis through inositol lipid turnover in Swiss 3T3 fibroblast. J Biol Chem $1989 ; 264: 7856-7861$.

12. Simonson MS, Wann S, Men P, Dubyal GR, Kester M, Nakazato Y, Sedor JR, Dunn MJ : Endothelin stimulates phospholipase $\mathrm{C}, \mathrm{Na} / \mathrm{H}$ exchange, c-fos expression, and mitogenesis in rat mesangial cells. J Clin Invest $1989 ; 83: 708-712$.

13. Shichiri M, Hirata Y, Nakajima T, Ando K, Imai T, 
Yanagisawa M, Masaki T, Marumo F : Endothelin-1 is an Autocrine/Paracrine Growth Factor for Human Cancer Cell Lines. J Clin Invest 1991 ; 87 : 1867-1871.

14. Lam H-C, Takahashi K, Ghatei MA, Suda K, Kanse SM, Bloom SR: Presence of immunoreactive endothelin in human saliva and rat parotid gland. Peptide $1991 ; 12$ : 883-885.

15. Jinnnouchi K, Tomiyama S, Pawankar R: Distribution of Endothelin-1 like Activity in the Endolymphatic Sac of Normal Guinea Pigs. Acta Otolaryngol (Stockh) $1995 ; 115$ : 400-404.

16. Cawson R, Gleeson M: Physiology of salivary secretion. Scott-Brown's Otolaryngology sixed ed. 1997 ; pp 1/9/7-1/9/13 Butterworth-Heinemann. Oxford.

17. Bundgaard M, Moller M, Poulson JH : Localization of sodium pump sites in cat salivary gland. Am J Physiol 1954; 178: 155-159.

18. Eversole LR: Histogenic classification of salivary tumors. Arch Pathol $1971 ; 92: 433-442$.

19. Regezi JA, Batsaxis JG: Histogenesis of salivary gland neoplasms. Otolaryngologic Clinics of North Am $1977 ; 10: 297-307$.
20. Nishiyama Y: The Mechanism of Positive Scintigraphy with $99 \mathrm{mTc}$-Pertechnetate in Adenolymphoma of the Parotid Gland. J Otolaryngol Jpn $1998 ; 101: 615^{-619}$.

21. Brown KD, Littlewood JA: Endothelin stimulates DNA synthesis in Swiss 3T3 cells. Biochem 1989; 163: 977-980.

22. Eguchi K, Kawakami A, Nakashima M, Ida H, Sakito S, Sakai M, Terada K, Kawabe Y, Fukuda $T$, Ishikawa N, Ito K, Nagataki S: Stimulation of mitogenesis in human thyroid epithelial cells by endothelin. Acta Endocrinologica 1993; 128 : 215-220.

23. Stiles JD, Ostrow PT, Balos LL, Greenberg JG, Plunkett R, Grand W, Heffner RR: Correction of Endothelin-1 and Transforming Growth factor $\beta 1$ with Malignancy and vascularity in Human Glioma. J Neuropathol Experimental Neurol 1997; 56: $435-439$.

24. Kojima K, Nihei $Z$ : Expression of endothelin-1 immunoreactivity in breast cancer. Surgical On cology $1995 ; 4: 309-315$.

(Received, June 22, 1998) (Accepted for publication, September 8, 1998) 